\title{
Responses of a Waterhemp (Amaranthus tuberculatus) Population Resistant to HPPD-Inhibiting Herbicides to Foliar-Applied Herbicides
}

\author{
Nicholas E. Hausman, Patrick J. Tranel, Dean E. Riechers, and Aaron G. Hager*
}

Field and greenhouse experiments were conducted to characterize the response of a waterhemp population from McLean County, IL to foliar-applied 4-hydroxyphenylpyruvate dioxygenase (HPPD) -inhibiting herbicides and determine the population's sensitivity to herbicides from other site-of-action groups. In the field, 10 to $15-\mathrm{cm}$-tall waterhemp treated with mesotrione at $105 \mathrm{~g}$ ai $\mathrm{ha}^{-1}$, tembotrione at $92 \mathrm{~g}$ ai ha $\mathrm{h}^{-1}$, or topromezone at $18 \mathrm{~g}$ ai ha ${ }^{-1}$ had significantly greater biomass $(\geq 10 \%) 14 \mathrm{~d}$ after treatment (DAT) than waterhemp harvested the day of herbicide application, indicating growth had occurred following herbicide application. Waterhemp growth stage at the time of herbicide application influenced control. Mesotrione applied at $105 \mathrm{~g} \mathrm{ha}^{-1}$ alone or combined with atrazine at $560 \mathrm{~g}$ ai ha ${ }^{-1}$ provided significantly greater waterhemp control $(\geq 66 \%)$ when applied to small waterhemp plants ( 2 to $5 \mathrm{~cm}$ tall) compared with applications made to plants 5 to 10 or 10 to $15 \mathrm{~cm}$ tall. Glyphosate, glufosinate, fomesafen, lactofen, or acifluorfen provided greater waterhemp control ( $\geq 68 \%) 7$ and 14 DAT than mesotrione, dicamba, or 2,4-D. Control of this population with atrazine, chlorimuron, and imazethapyr did not exceed $12 \%$. Results of a greenhouse experiment with waterhemp plants grown from field-collected seed were similar to field data, and confirm the McLean County population was poorly controlled with HPPD, photosystem II, and acetolactate synthase inhibitors.

Nomenclature: Acifluorfen; atrazine; chlorimuron; dicamba; fomesafen; glufosinate; glyphosate; imazethapyr; lactofen; mesotrione; tembotrione; topramezone; 2,4-D; waterhemp, Amaranthus tuberculatus (Moq.) Sauer var. rudis (Sauer) Costea and Tardif AMATU.

Key words: Herbicide resistance, waterhemp management.

\begin{abstract}
Experimentos de campo e invernadero fueron realizados para caracterizar la respuesta de una población de Amaranthus tuberculatus proveniente del condado McLean en Illinois, a la aplicación foliar de herbicidas inhibidores de 4hydroxyphenylpyruvate dioxygenase (HPPD) y determinar la sensibilidad de la población a herbicidas de grupos con otros sitios de acción. En el campo, plantas de $A$. tuberculatus de 10 a $15 \mathrm{~cm}$ de altura, tratadas con mesotrione a $105 \mathrm{~g}$ ai ha $^{-1}$, tembotrione a $92 \mathrm{~g}$ ai ha ${ }^{-1}$, o topramezone a $18 \mathrm{~g}$ ai ha $^{-1}$, tuvieron una biomasa significativamente mayor $(\geq 10 \%) 14 \mathrm{~d}$ después del tratamiento (DAT) que $A$. tuberculatus cosechado el día de la aplicación del herbicida, indicando que hubo crecimiento después de la aplicación del herbicida. El estadio de desarrollo de $A$. tuberculatus al momento de la aplicación del herbicida influyó en el control. Mesotrione aplicado solo a $105 \mathrm{~g} \mathrm{ha}^{-1}$ o combinado con atrazine a $560 \mathrm{~g}$ ai ha ${ }^{-1}$ brindó un control significativamente mayor $(\geq 66 \%)$ cuando se aplicó a plantas pequeñas de $A$. tuberculatus $(2$ a $5 \mathrm{~cm} \mathrm{de} \mathrm{altura),} \mathrm{al}$ compararse con aplicaciones hechas a plantas de 5 a 10 ó 10 a $15 \mathrm{~cm}$ de altura. Glyphosate, glufosinate, fomesafen, lactofen, o acifluorfen brindaron mayor control de $A$. tuberculatus $(\geq 68 \%) 7$ y 14 DAT que mesotrione, dicamba, o 2,4-D. El control de esta población con atrazine, chlorimuron, e imazethapyr no excedió $12 \%$. Los resultados de un experimento de invernadero con plantas de $A$. tuberculatus provenientes de semillas colectadas en campo, fueron similares a los datos de campo, y confirman que la población del condado McLean fue pobremente controlada con herbicidas inhibidores de HPPD, fotosistema II, y acetolactate synthase.
\end{abstract}

Waterhemp is a small-seeded, dioecious, summer annual broadleaf weed species (Sauer 1955, 1957) common in Illinois corn (Zea mays L.) and soybean [Glycine max (L.) Merr] production systems (Hager et al. 1997). Previous research has demonstrated this

\footnotetext{
DOI: 10.1614/WT-D-15-00098.1

* Graduate Research Assistant, Professor, Professor, Associate Professor, respectively, Department of Crop Sciences, University of Illinois, Urbana, IL 61801. Corresponding author's E-mail: hager@illinois.edu
}

weed species can reduce soybean yield more than $40 \%$ (Hager et al. 2002) and corn yield more than 70\% (Steckel and Sprague 2004). Once established, this species is difficult to eradicate, as individual female plants can produce in excess of one million seeds (Hartzler et al. 2004; Steckel et al. 2003) that can remain dormant in the soil seed bank for several years (Buhler and Hartzler 2001; Burnside et al. 1996). Waterhemp emergence occurs over a more prolonged period than other weed species, such as 
velvetleaf (Abutilon theophrasti Medicus) and foxtail (Setaria spp.) (Hartzler et al. 1999). Waterhemp's extended emergence characteristic often necessitates an integrated management system, including utilization of soil-residual and foliar-applied herbicides, to manage this species adequately.

The evolution of waterhemp populations resistant to foliar-applied herbicides has effectively reduced viable herbicide options for control of waterhemp in certain agronomic crops such as corn and soybean. Prior to 2009, waterhemp had evolved resistance to herbicides from four site-of-action groups (Heap 2013): acetolactate synthase (ALS) inhibitors, photosystem II (PSII) inhibitors, protoporphyrinogen oxidase (PPO) inhibitors, and 5-enolpyruvylshikimate-3-phosphate synthase (EPSPS) inhibitors. Waterhemp resistant to multiple herbicide groups further limits control options (Foes et al. 1998; Patzoldt et al. 2005). Bell et al. (2013) identified a population of waterhemp in which individual plants demonstrated resistance to herbicides from four site-of-action groups.

Resistance to 4-hydroxyphenylpyruvate dioxygenase (HPPD) -inhibiting herbicides is a relatively recent phenomenon with the first instances reported in 2009 (Heap 2013). Waterhemp populations from McLean County, IL (Hausman et al. 2011) and Henry County, IA (McMullan and Green 2011) have been documented resistant to HPPDinhibiting herbicides. Two biotypes of Palmer amaranth (Amaranthus palmeri S. Wats.) from Kansas have demonstrated reduced sensitivity to various HPPD-inhibiting herbicides (Lally et al. 2010). In greenhouse and laboratory research, waterhemp grown from seed collected at the McLean County, IL location demonstrated resistance to foliar-applied mesotrione, tembotrione, and topramezone at rates of 105,92 , and $18 \mathrm{~g}$ ai $\mathrm{ha}^{-1}$, respectively, and resistance to the PSII inhibitor atrazine (Hausman et al. 2011; Ma et al. 2013). Additional greenhouse research revealed the Illinois waterhemp population demonstrated a 10 to 35-fold level of resistance to the HPPD inhibitor mesotrione (Hausman et al. 2011). McMullan and Green (2011) reported similar greenhouse results with the Iowa waterhemp population, which demonstrated an 8-fold level of resistance to mesotrione as well as resistance to atrazine (10fold) and thifensulfuron (28-fold).
Previous research (Hausman et al. 2011) with the Illinois HPPD-inhibitor-resistant population was conducted solely under greenhouse conditions with herbicides representing only two site-of-action groups. The goal of the research presented herein was to characterize this particular waterhemp population further. Our objectives were (1) to quantify biomass accumulation under field conditions using a rate-response experiment with HPPD inhibitors applied alone or in combination with atrazine, (2) to characterize the response to mesotrione applied alone or with atrazine at various waterhemp growth stages under field conditions, and (3) to determine the response to various foliarapplied herbicides representing multiple site-ofaction groups both in the field and greenhouse. The additional comprehensive characterization of this population's response to foliar-applied herbicides could potentially augment management decisions for other HPPD-inhibiting herbicideresistant Amaranthus populations (Heap 2013).

\section{Materials and Methods}

Field Experiments. Field experiments were conducted in 2010 and 2011 at the location (McLean County, IL) from which the HPPD-inhibitorresistant waterhemp population (designated MCR) was initially identified (Hausman et al. 2011). The soil was a Sable silty clay loam (fine-silty, mixed, superactive, mesic Typic Endoaquolls), with a $\mathrm{pH}$ of 6.4 and $3.2 \%$ organic matter. Preplant tillage was performed each spring to prepare the seedbed for planting and to control emerged weeds. Experiments were conducted either in corn or soybean, planted in 76-cm rows. Experiments were designed as randomized complete blocks with three replications of each treatment. Individual replications were plots measuring 3 by $7.6 \mathrm{~m}$ that included four crop rows. Herbicides were applied with a pressurized $\mathrm{CO}_{2}$ backpack sprayer equipped with AIXR110025 nozzles (TeeJet Technologies, P.O. Box 7900, Wheaton, IL 60187) spaced $51 \mathrm{~cm}$ apart on a 3$\mathrm{m}$ boom calibrated to deliver $187 \mathrm{~L} \mathrm{ha}^{-1}$ at 276 $\mathrm{kPa}$. Herbicides and accompanying additives that are commonly used in Illinois cropping systems were selected for evaluation. Application rate of each herbicide was based on the respective label recommendations for waterhemp control according to soil type and organic matter content (Table 1). 
Table 1. Herbicides used, application rates, and source information for field (McLean County, IL) and greenhouse trials.

\begin{tabular}{|c|c|c|c|c|}
\hline Common name & Trade name & $\begin{array}{l}\text { Site of } \\
\text { action }^{\text {a }}\end{array}$ & Application rate(s) & Manufacturer \\
\hline & & & $\mathrm{g}$ ai ha ${ }^{-1}$ & \\
\hline Imazethapyr & Pursuit & ALS & 70 & $\begin{array}{l}\text { BASF Corporation Agricultural Products, Research Triangle } \\
\text { Park, NC; http://www.agro.basf.com }\end{array}$ \\
\hline Glufosinate & Ignite & GS & 450 & $\begin{array}{l}\text { Bayer CropScience, Research Triangle Park, NC; } \\
\text { http://www.bayercropscience.com }\end{array}$ \\
\hline Mesotrione & Callisto & HPPD & $105,210,420$ & $\begin{array}{l}\text { Syngenta Crop Protection, Greensboro, NC; } \\
\text { http://www.syngentacropprotection.com }\end{array}$ \\
\hline Tembotrione & Laudis & HPPD & $92,184,368$ & $\begin{array}{l}\text { Bayer CropScience, Research Triangle Park, NC; } \\
\text { http://www.bayercropscience.com }\end{array}$ \\
\hline Fomesafen & Flexstar & $\mathrm{PPO}$ & 395 & $\begin{array}{l}\text { Syngenta Crop Protection, Greensboro, NC; } \\
\text { http://www.syngentacropprotection.com }\end{array}$ \\
\hline Lactofen & Cobra & PPO & 140 & $\begin{array}{l}\text { Valent U.S.A. Corporation, Walnut Creek, CA; } \\
\text { http://www.valent.com }\end{array}$ \\
\hline Atrazine & AAtrex & PSII & 560,1680 & $\begin{array}{l}\text { Syngenta Crop Protection, Greensboro, NC; } \\
\text { http://www.syngentacropprotection.com }\end{array}$ \\
\hline $2,4-\mathrm{D}$ & 2,4-D, Ester & $\begin{array}{l}\text { Synthetic } \\
\text { auxin }\end{array}$ & $270^{\mathrm{b}}$ & $\begin{array}{l}\text { Dow AgroSciences, Indianapolis, IN; } \\
\text { http://www.dowagro.com }\end{array}$ \\
\hline Dicamba & Clarity & $\begin{array}{l}\text { Synthetic } \\
\text { auxin }\end{array}$ & $280^{\mathrm{b}}$ & $\begin{array}{l}\text { BASF Corporation Agricultural Products, Research Triangle } \\
\text { Park, NC; http://www.agro.basf.com }\end{array}$ \\
\hline
\end{tabular}

a Abbreviations: ALS, acetolactate synthase; EPSPS, 5-enolpyruvylshikimate-3-phosphate synthase; GS, glutamine synthetase; HPPD, 4-hydroxyphenylpyruvate dioxygenase; PPO, protoporphyrinogen oxidase; PSII, photosystem II.

b Acid equivalent $\left(\mathrm{g}\right.$ ae $\left.\mathrm{ha}^{-1}\right)$.

All herbicide applications were made when the majority of waterhemp plants were 10 to $15 \mathrm{~cm}$ tall unless noted otherwise.

Three separate field experiments were implemented to address the research objectives. In a rateresponse experiment, biomass accumulation of MCR was quantified following treatment with one of three HPPD inhibitors (mesotrione, tembotrione, or topramezone) applied at the recommended field use rate $\left(105,92\right.$, and $18 \mathrm{~g}$ ai ha ${ }^{-1}$, respectively), as well as at twice and four times the recommended rate. HPPD-inhibitor treatments were applied alone or in combination with atrazine at $560 \mathrm{~g}$ ai $\mathrm{ha}^{-1}$. Another experiment determined

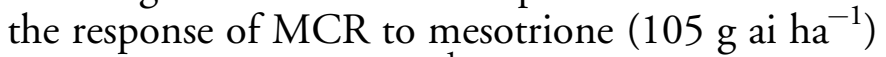
\pm atrazine $\left(560 \mathrm{~g} \mathrm{ai} \mathrm{ha}^{-1}\right.$ ) following treatment of waterhemp plants at three discrete growth stages (2 to 5,5 to 10 , or 10 to $15 \mathrm{~cm}$ tall). The response of MCR to 11 herbicides, representing seven herbicide site-of-action groups, was determined in a third experiment.

Greenhouse Experiment. Inflorescences of several female waterhemp plants not controlled following foliar applications of tembotrione and mesotrione (92 and $105 \mathrm{~g}$ ai ha $^{-1}$, respectively) were collected from the McLean location in August 2009. The progeny from these harvested waterhemp plants were chosen to characterize the response of MCR to herbicides from different site-of-action groups under greenhouse conditions. One milliliter of seeds from each of the 12 inflorescences was combined in a single glass vial and shaken to create a greenhouse population representative of the field population rather than representative of the individual female plants. Seeds from this mixture were then stratified in a $0.1 \%$ agarose solution at $4 \mathrm{C}$ for $30 \mathrm{~d}$. The response of MCR to various foliarapplied herbicides was compared with the responses 
of two other waterhemp populations (designated ACR and WCS) sensitive to HPPD-inhibiting herbicides. The ACR population demonstrates resistance to ALS-, PSII-, and PPO-inhibiting herbicides (Patzoldt et al. 2005), whereas WCS displays no resistance to herbicides from any site-ofaction group (Patzoldt et al. 2002).

Waterhemp plants from all three populations were grown from seeds sown in 12- by $12-\mathrm{cm}$ flats containing a commercial potting medium (Sun Gro Horticulture, 15831 Northeast 8th Street, Bellevue, WA 98008). Emerged seedlings $(2 \mathrm{~cm})$ were transplanted into $950-\mathrm{cm}^{3}$ pots (one seedling per pot) containing a $3: 1: 1: 1$ mixture of potting mix : soil : peat : sand that included a slow-release fertilizer (The Scotts Company, 14111 Scottslawn Road, Marysville, OH 43041). Greenhouse conditions were maintained at 28/22 C day/night with a $16-\mathrm{h}$ photoperiod. Natural sunlight was supplemented with mercury halide lamps to provide 800 $\mu \mathrm{mol} \mathrm{m}{ }^{-2} \mathrm{~s}^{-1}$ photon flux at the plant canopy.

Uniformly sized waterhemp plants $(10$ to $12 \mathrm{~cm}$ tall) from MCR, ACR, and WCS were treated with one of eight herbicides evaluated (Table 1). Treatments were applied with a compressed-air research sprayer (DeVries Manufacturing, 28081 870th Avenue, Hollandale, MN 56045) fitted with a TeeJet 80015 EVS nozzle. The nozzle was situated $46 \mathrm{~cm}$ above the plant canopy, and the sprayer was calibrated to deliver $185 \mathrm{~L} \mathrm{ha}^{-1}$ at $275 \mathrm{kPa}$. After herbicide application, plants were moved back to the greenhouse and arranged in a completely randomized design (CRD). Treatments applied to WCS and ACR were replicated four times, whereas treatments applied to MCR were replicated 48 times, and the experiment was conducted twice.

Data Collection. Visual estimates of percent waterhemp control were recorded on a scale of 0 (no control) to 100 (complete control). These estimates were based on waterhemp injury and growth reduction compared with the untreated control. In addition to visual estimates, four uniformly sized waterhemp plants per plot (12 per treatment) were selected prior to treatment to quantify aboveground biomass accumulation following herbicide application in the rate-response field experiment. These uniformly sized waterhemp plants $(10$ to $15 \mathrm{~cm}$ ) were marked by placing a small plastic stake near each plant prior to herbicide application. All other waterhemp plants within a $15-\mathrm{cm}$ diam of each marked plant were carefully removed to ensure full spray interception by the marked plants. Twelve additional plants at a similar growth stage to the marked waterhemp (10 to 15 $\mathrm{cm}$ ) were harvested prior to herbicide application to determine pretreatment biomass. Each year, all marked waterhemp plants (including those in nontreated plots) were harvested $14 \mathrm{~d}$ after treatment (DAT), dried at $65 \mathrm{C}$ for $7 \mathrm{~d}$, and weights recorded. Mortality of treated plants was recorded in 2011. Identical measurements as were collected in field experiments (percent control, dry weight, and mortality) were made for all waterhemp plants in the greenhouse experiment, except that harvest occurred 21 DAT.

Statistical Analyses. Statistical analysis for field and greenhouse trials was performed with the use of PROC Mixed in SAS 9.2 (SAS Institute, Inc., 100 SAS Campus Drive, Cary, NC 27513). Fixed effects included herbicide treatment and waterhemp population (greenhouse only). Random effects included year and block within year (field only), or experimental run (greenhouse only). Mean estimates of percent waterhemp control were compared with the use of single-degree-of-freedom contrast statements or separated with the use of the SAS macro \%pdmix800 (Saxton 1998). All dry-weight data (field and greenhouse) were analyzed with the use of the SAS statement REPEATED/GROUP, as fit statistics revealed the heterogeneous variance structure fit the data better than the homogeneous variance structure.

\section{Results and Discussion}

Rate Response with HPPD Inhibitors Applied Alone or Combined with Atrazine. Regardless of application rate, mesotrione, tembotrione, or topramezone controlled MCR less than $40 \% 7$ or 14 DAT (Table 2). These results from a field experiment are similar to those reported by Hausman et al. (2011), who evaluated the response of MCR to these herbicides under greenhouse conditions. The addition of atrazine increased waterhemp control 14 DAT only with tembotrione at 184 and $368 \mathrm{~g} \mathrm{ha}^{-1}$ and mesotrione at $420 \mathrm{~g} \mathrm{ha}^{-1}$ when compared with each HPPD inhibitor applied alone.

By 14 DAT, biomass of waterhemp treated with $1 \mathrm{x}$ rates of mesotrione, tembotrione, or topramezone $\left(105,92\right.$, and $18 \mathrm{~g} \mathrm{ha}^{-1}$, respectively) was 
Table 2. Visual estimates of control and mean biomass of McLean County, IL waterhemp under field conditions (2010 and 2011$){ }^{a}$ Visual estimates of control sharing the same letter within a column are not significantly different at $\alpha=0.05$ (separated by the SAS macro \%pdmix800).

\begin{tabular}{|c|c|c|c|c|c|c|}
\hline Herbicide $^{b}$ & Rate & $7 \mathrm{DAT}^{\mathrm{c}}$ & $14 \mathrm{DAT}^{\mathrm{c}}$ & Biomass & $\begin{array}{l}\text { Estimated } \\
\text { difference }^{e}\end{array}$ & $\operatorname{Pr}>F$ \\
\hline & $\mathrm{g}$ ai ha ${ }^{-1}$ & 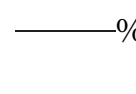 & $\mathrm{rol}$ & $\begin{array}{c}\% \text { of nontreated } \\
14 \mathrm{DAT}^{\mathrm{c}}\end{array}$ & $\%$ & \\
\hline Pretreatment plants ${ }^{\mathrm{d}}$ & - & - & - & 21 & - & - \\
\hline \multirow[t]{2}{*}{ Mesotrione } & 105 & $28 \mathrm{bc}$ & $21 \mathrm{ef}$ & 38 & 17 & $0.0065^{*}$ \\
\hline & 210 & $28 \mathrm{bc}$ & $24 \operatorname{def}$ & 27 & 6 & 0.2866 \\
\hline \multirow[t]{3}{*}{ Tembotrione } & 92 & $26 \mathrm{bc}$ & 18 ef & 31 & 10 & $0.0420^{*}$ \\
\hline & 184 & $27 \mathrm{bc}$ & 23 def & 31 & 10 & $0.0088^{*}$ \\
\hline & 368 & $31 \mathrm{ab}$ & 33 cde & 21 & 0 & 0.9546 \\
\hline \multirow[t]{3}{*}{ Topramezone } & 18 & $24 \mathrm{bc}$ & 17 ef & 43 & 22 & $0.0073^{*}$ \\
\hline & 36 & $26 \mathrm{bc}$ & 19 ef & 30 & 9 & 0.1449 \\
\hline & 72 & $33 \mathrm{ab}$ & 36 bcde & 22 & 1 & 0.8194 \\
\hline \multirow{2}{*}{ Tembotrione + atrazine } & $184+560$ & $48 \mathrm{ab}$ & $50 \mathrm{abc}$ & 12 & -9 & 0.0014 \\
\hline & $368+560$ & $48 \mathrm{ab}$ & $58 \mathrm{ab}$ & 11 & -10 & 0.0001 \\
\hline \multirow[t]{3}{*}{ Topramezone + atrazine } & $18+560$ & $35 \mathrm{ab}$ & 33 cde & 16 & -5 & 0.2763 \\
\hline & $36+560$ & $38 \mathrm{ab}$ & 35 bcde & 14 & -7 & 0.0049 \\
\hline & $72+560$ & $40 \mathrm{ab}$ & 46 abcd & 12 & -9 & 0.0018 \\
\hline Atrazine & 560 & $4 \mathrm{c}$ & $3 \mathrm{f}$ & 82 & 61 & $0.0001^{*}$ \\
\hline
\end{tabular}

* Significant at $\alpha=0.05$, treatments with positive differences indicate growth after treatment. Separated with the use of Dunnett's procedure in SAS.

a Trial was planted to corn.

b All treatments containing HPPD inhibitors included crop oil concentrate (COC) at 1\% (v/v) and $28 \%$ urea ammonium nitrate (UAN) at $2.5 \%(\mathrm{v} / \mathrm{v})$; COC was included with the atrazine-only treatment.

${ }^{\mathrm{c}}$ Days after treatment.

d Plants harvested the day of spraying to assess biomass accumulation after herbicide application.

e Estimated difference in dry weight (as a \% of the untreated) between herbicide-treated plants and pretreatment plants.

significantly greater than the biomass of pretreatment waterhemp (Table 2) indicating plant recovery and growth had occurred following herbicide application. Biomass of waterhemp plants treated with the $2 \mathrm{x}$ rate of tembotrione $\left(184 \mathrm{~g} \mathrm{ha}^{-1}\right)$ or atrazine $\left(560 \mathrm{~g} \mathrm{ha}^{-1}\right)$ also was significantly greater than pretreatment biomass. Although average biomass was either less or not different from pretreatment biomass for all other treatments, waterhemp control estimates recorded 7 and 14 DAT indicate generally poor control of this population.

Mortality data were collected in 2011 as an additional metric to describe the response of the MCR waterhemp population to foliar-applied HPPD-inhibiting herbicides. Mortality of the 12 waterhemp plants (those marked prior to herbicide application) did not exceed $17 \%$ when treated with $1 \mathrm{x}$ rates of mesotrione, tembotrione, or topramezone alone or $58 \%$ when in combination with atrazine (data not shown). Plants were considered survivors if they displayed actively growing, nonbleached tissue around the apical meristem.

These results are in general agreement with other published reports. McMullan and Green (2011) reported waterhemp control was less than $70 \%$ at the Henry County, IA location 30 DAT with mesotrione, tembotrione, or topramezone applied at twice the recommended field use rates of 105, 92, and $18 \mathrm{~g} \mathrm{ha}^{-1}$, respectively. Mortality of waterhemp generated from seed collected from the McLean location and treated with mesotrione at $315 \mathrm{~g} \mathrm{ha}^{-1}$ was only 33\% (Hausman et al. 2011). Lally et al. (2010) reported two putative HPPD-resistant 
Table 3. Visual estimates of McLean County, IL waterhemp control, contrast statements, and 95\% confidence intervals after foliar applications of mesotrione and atrazine alone or in combination under field conditions (2010 and 2011). . Application timings were based on waterhemp height.

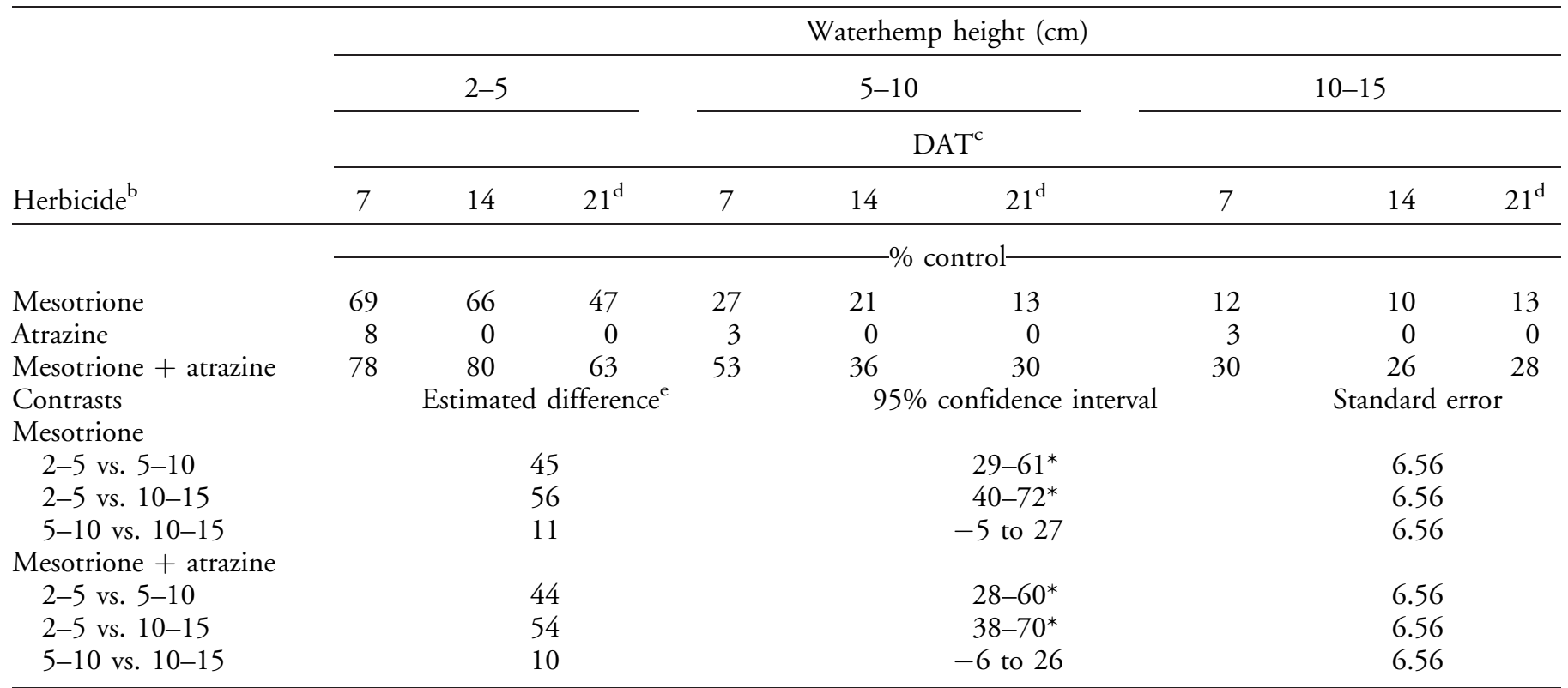

* Significant at $\alpha=0.05$.

${ }^{\text {a }}$ Trial was planted to corn.

${ }^{\mathrm{b}}$ Mesotrione and atrazine rates were 105 and $560 \mathrm{~g} \mathrm{ai} \mathrm{ha}^{-1}$, respectively. Treatments included crop oil concentrate (COC) at $1 \%(\mathrm{v} /$ v) and ammonium sulfate (AMS) at $2.5 \%(\mathrm{v} / \mathrm{v})$.

${ }^{\mathrm{c}}$ Days after treatment.

${ }^{\mathrm{d}} 21$ DAT ratings taken only in 2011.

${ }^{\mathrm{e}}$ Estimated difference of mean control between application timings within mesotrione alone or mesotrione plus atrazine 14 DAT.

Palmer amaranth biotypes required 11 and 5 times more pyrasulfotole plus bromoxynil than a sensitive biotype to achieve 50\% mortality. The decreased effectiveness of the HPPD inhibitors and atrazine observed within the MCR population is most likely due to elevated metabolism (Ma et al. 2013).

Response to Mesotrione Applied at Three Discrete Growth Stages. By 7 DAT, regardless of growth stage, mesotrione caused characteristic HPPD-inhibitor symptomatology on treated waterhemp plants, including bleached foliage and stunted growth (Table 3). Similar to Vyn et al. (2006) and Woodyard et al. (2009), combining atrazine with mesotrione generally increased waterhemp control compared with mesotrione alone. Control with atrazine alone did not exceed 8\% regardless of growth stage, similar to greenhouse results reported by Hausman et al. (2011). Waterhemp control generally decreased by 14 DAT for all treatments, except mesotrione plus atrazine applied at the 2 to $5-\mathrm{cm}$ growth stage. The decrease in control was attributed to recovery of treated plants, manifested by new, noninjured leaf tissue emerging from apical meristems and axillary buds. Contrast statements (Table 3) comparing growth-stage application timing 14 DAT demonstrated that control was significantly greater when mesotrione was applied to 2 to 5-cm-tall waterhemp compared with applications made at 5 to 10 or 10 to $15 \mathrm{~cm} \mathrm{(45} \mathrm{and} \mathrm{56 \%}$ greater, respectively). There was no significant difference in waterhemp control between plants treated with mesotrione at 5 to 10 and 10 to $15 \mathrm{~cm}$ tall. Results were similar when mesotrione was combined with atrazine (Table 3 ).

Greater weed control when mesotrione was applied to smaller weeds has been documented previously. Johnson et al. (2002) reported increased control of common cocklebur (Xanthium strumarium L.) and yellow nutsedge (Cyperus esculentus L.) 14 DAT following early postemergence mesotrione applications (weed height 3 to $8 \mathrm{~cm}$ ) as compared with control following later applications (weed height $\geq 15 \mathrm{~cm}$ ). Woodyard et al. (2009) reported 
Table 4. Visual estimates of McLean County, IL waterhemp control 7 and $14 \mathrm{~d}$ after treatment (DAT) with herbicides representing seven site-of-action groups under field conditions (2010 and 2011). ${ }^{a}$ Ratings with the same letter within a column are not significantly different at $\alpha=0.05$ (separated by the SAS macro \%pdmix800). ${ }^{\text {b }}$

\begin{tabular}{|c|c|c|c|c|c|}
\hline Herbicide & Site of action ${ }^{b}$ & Additives & Rate & 7 DAT & $14 \mathrm{DAT}$ \\
\hline Chlorimuron & ALS & NIS + UAN & 11.2 & $8 \mathrm{c}$ & $6 \mathrm{e}$ \\
\hline Glyphosate & EPSPS & AMS & $840^{\mathrm{C}}$ & $88 \mathrm{a}$ & $89 \mathrm{a}$ \\
\hline Glufosinate & GS & AMS & 450 & $81 \mathrm{a}$ & $68 \mathrm{~b}$ \\
\hline Mesotrione & HPPD & $\mathrm{COC}+\mathrm{UAN}$ & 105 & $30 \mathrm{~b}$ & $19 \mathrm{~cd}$ \\
\hline Fomesafen & $\mathrm{PPO}$ & $\mathrm{COC}+\mathrm{UAN}$ & 395 & $93 a$ & 89 a \\
\hline Lactofen & $\mathrm{PPO}$ & $\mathrm{COC}+\mathrm{UAN}$ & 140 & $90 \mathrm{a}$ & $87 \mathrm{a}$ \\
\hline Atrazine & PSII & $\mathrm{COC}+\mathrm{UAN}$ & 1680 & $8 \mathrm{c}$ & 8 de \\
\hline $2,4-\mathrm{D}$ & Synthetic auxin & - & $270^{\mathrm{c}}$ & $23 \mathrm{bc}$ & $16 \mathrm{cde}$ \\
\hline Dicamba & Synthetic auxin & NIS & $280^{\mathrm{C}}$ & $33 \mathrm{~b}$ & $26 \mathrm{c}$ \\
\hline
\end{tabular}

${ }^{\text {a }}$ Trial was planted to soybean.

b Abbreviations: ALS, acetolactate synthase; EPSPS, 5-enolpyruvylshikimate-3-phosphate synthase; GS, glutamine synthetase; HPPD, 4-hydroxyphenylpyruvate dioxygenase; PPO, protoporphyrinogen oxidase; PSII, photosystem II; NIS, nonionic surfactant at $0.25 \%(\mathrm{v} / \mathrm{v})$; UAN, $28 \%$ urea ammonium nitrate at 2.5\% (v/v); COC, crop oil concentrate at $1 \%(\mathrm{v} / \mathrm{v})$; AMS, ammonium sulfate at $2.5 \%(\mathrm{v} / \mathrm{v})$.

${ }^{\mathrm{c}}$ Acid equivalent $\left(\mathrm{g}\right.$ ae $\left.\mathrm{ha}^{-1}\right)$.

decreased common lambsquarters (Chenopodium album L.) control with mesotrione plus atrazine between years, partially because of increased weed height one year. Although waterhemp control with mesotrione alone or combined with atrazine was greatest following the 2 to $5-\mathrm{cm}$ application timing, many treated waterhemp plants recovered and resumed growth. Additional management practices, such as interrow cultivation or utilization of a different site-of-action herbicide, would be needed to reduce additional weed interference and seed production. More waterhemp plants survived following herbicide applications made at later growth stages $(\geq 5 \mathrm{~cm})$, reflected in the estimates of control (Table 3). The results of the present experiments demonstrate foliar-applied HPPD inhibitors are not viable options for control of this Illinois waterhemp population. Additional research was undertaken to determine what other foliarapplied herbicides remain viable options for control of this population.

\section{Response to Herbicides from Other Site-of-} Action Groups under Field Conditions. By 7 DAT, control of MCR was greatest with acifluorfen, fomesafen, lactofen, glyphosate, and glufosinate, ranging from 81 to $93 \%$ (Table 4). Poor control with mesotrione $(30 \%)$ and atrazine $(8 \%)$ was consistent with previously reported results
(Hausman et al. 2011). 2,4-D and dicamba provided less than $35 \%$ control, and control with the ALS inhibitors chlorimuron and imazethapyr was $12 \%$ or less. At 14 DAT, the PPO inhibitors and glyphosate provided the greatest waterhemp control (75 to 89\%). Control with glufosinate (68\%) was less than glyphosate and all PPO inhibitors except aciflurofen. Waterhemp control ranged from 16 to $26 \%$ with mesotrione, 2,4-D, and dicamba, whereas control with atrazine, chlorimuron, or imazethapyr was less than $10 \%$.

The response of MCR to atrazine and ALS inhibitors was not unexpected. A survey of 59 Illinois waterhemp populations in 1998 to 1999 revealed $22 \%$ of populations contained individuals displaying resistance to both PSII and ALS inhibitors (Patzoldt et al. 2002). Obligate outcrossing coupled with production of large quantities of mobile seeds (Tranel et al. 2010) has undoubtedly aided the spread of these resistance traits throughout Illinois over the last decade. Additionally, the McLean field was treated with soil- and foliarapplied triazine herbicides for at least seven consecutive years (Hausman et al. 2011), which likely increased the selection for triazine-resistant waterhemp. Guo et al. (2015) reported that MCR contains both target and non-target-site mechanisms that confer resistance to ALS inhibitors. 
Table 5. Mean visual estimates of control of HPPD-inhibitor resistant (MCR) and sensitive (ACR and WCS) waterhemp populations 7, 14, and $21 \mathrm{~d}$ after treatment (DAT) under greenhouse conditions. Means sharing the same letter within their respective evaluation period $(7,14$, or $21 \mathrm{DAT}$ ) are not significantly different at $\alpha=0.05$ (separated by the SAS macro $\% p d m i x 800$ ).

\begin{tabular}{|c|c|c|c|c|c|c|c|c|c|c|c|}
\hline \multirow[t]{2}{*}{ Herbicide } & \multirow[t]{2}{*}{ Site of action ${ }^{a}$} & \multirow{2}{*}{$\frac{\text { Rate }}{\mathrm{g}_{\text {ai ha }}{ }^{-1}}$} & \multicolumn{3}{|c|}{7 DAT } & \multicolumn{3}{|c|}{$14 \mathrm{DAT}$} & \multicolumn{3}{|c|}{$21 \mathrm{DAT}$} \\
\hline & & & WCS & ACR & MCR & WCS & ACR & MCR & WCS & ACR & MCR \\
\hline Imazethapyr & ALS & 70 & $89 \mathrm{abc}$ & $0 \mathrm{i}$ & $11 \mathrm{gh}$ & 89 abcd & $0 \mathrm{gh}$ & $7 \mathrm{gh}$ & $90 \mathrm{a}$ & 0 ef & $4 \mathrm{ef}$ \\
\hline Glyphosate & EPSPS & $840^{\mathrm{b}}$ & $96 a$ & $96 a$ & $76 \mathrm{~d}$ & $100 \mathrm{a}$ & $100 \mathrm{a}$ & $75 \mathrm{~d}$ & $100 \mathrm{a}$ & $100 \mathrm{a}$ & $70 \mathrm{c}$ \\
\hline Glufosinate & GS & 450 & $95 \mathrm{a}$ & $94 \mathrm{ab}$ & $92 \mathrm{a}$ & $100 \mathrm{a}$ & $96 \mathrm{ab}$ & $93 \mathrm{a}$ & $100 \mathrm{a}$ & $97 \mathrm{a}$ & $93 \mathrm{a}$ \\
\hline Lactofen & PPO & 140 & $96 \mathrm{a}$ & $48 \mathrm{f}$ & $88 \mathrm{ab}$ & $100 \mathrm{a}$ & $24 \mathrm{f}$ & $81 \mathrm{~cd}$ & $100 \mathrm{a}$ & $18 \mathrm{de}$ & $75 \mathrm{bc}$ \\
\hline Atrazine & PSII & 1680 & $91 \mathrm{ab}$ & 4 ghi & $4 \mathrm{i}$ & $98 \mathrm{ab}$ & $2 \mathrm{gh}$ & $2 \mathrm{~h}$ & $100 \mathrm{a}$ & $1 \mathrm{ef}$ & $1 \mathrm{f}$ \\
\hline Dicamba & $\begin{array}{c}\text { Synthetic } \\
\text { auxin }\end{array}$ & $280^{\mathrm{b}}$ & $82 \mathrm{bcd}$ & $86 \mathrm{abcd}$ & $81 \mathrm{c}$ & 84 abcd & $86 \mathrm{abcd}$ & $84 \mathrm{bc}$ & $88 \mathrm{ab}$ & $90 \mathrm{a}$ & $87 \mathrm{a}$ \\
\hline
\end{tabular}

a Abbreviations: ALS, acetolactate synthase; EPSPS, 5-enolpyruvylshikimate-3-phosphate synthase; GS, glutamine synthetase; HPPD, 4-hydroxyphenylpyruvate dioxygenase; PPO, protoporphyrinogen oxidase; PSII, photosystem II.

${ }^{\mathrm{b}}$ Acid equivalent $\left(\mathrm{g}\right.$ ae ha $\left.{ }^{-1}\right)$.

Reduced waterhemp control with glufosinate 14 DAT was attributed primarily to regrowth of treated plants (Table 4). Hoss et al. (2003) reported similar findings, with glyphosate providing greater waterhemp control than glufosinate 14 DAT because of recovery of glufosinate-treated plants. Although a small number of PPO-inhibitor-treated plants displayed some regrowth, the magnitude of recovery was less than that of glufosinate-treated waterhemp (personal observation). Hager et al. (2003) observed a similar response when a small percentage of PPO-inhibitor-treated waterhemp plants recovered from lower leaf axils 14 DAT with the same PPO-inhibiting herbicides evaluated in the present research. PPO inhibitors and glufosinate cause rapid lipid peroxidation and cell-membrane destruction, but are not extensively translocated throughout the plant (Hess 2000; Matsumoto 2002). Thorough spray coverage is essential for these herbicides to control weeds, and the high infield waterhemp density at the McLean field location (Hausman et al. 2013) might have prevented thorough spray coverage on a small percentage of plants. Waterhemp treated with the synthetic auxins dicamba or 2,4-D displayed epinasty and leaf malformation; however, little stand reduction or mortality of treated plants had occurred by 14 DAT (Table 4). In order to eliminate the potentially confounding effects of varying climatic conditions and nonuniform spray coverage, additional research to characterize the response of the MCR population to various herbicide site-of-action groups was conducted under controlled greenhouse conditions.

Response to Herbicides from other Site-ofAction Groups under Greenhouse Conditions. Mean visual estimates of control for WCS, ACR, and MCR by treatment are presented in Table 5 . MCR response to mesotrione in the greenhouse was analogous to field results. Injury was greatest by 7 DAT (64\%), and thereafter declined over subsequent evaluations (26\% by 21 DAT). By 14 DAT, plants were demonstrating signs of recovery from initial injury, manifested by emergence of new, noninjured leaf tissue near the apical meristem and resumption of growth. Conversely, MCR plants treated with glyphosate, glufosinate, or dicamba did not demonstrate signs of recovery from 7 to 14 DAT. Atrazine, chlorimuron, and imazethapyr provided the least control of MCR, ranging from 1 to $7 \% 21$ DAT, whereas control with glyphosate, lactofen, dicamba, and glufosinate ranged from 70 to $93 \%$. MCR dry weight data revealed the highest amount of accrued plant biomass occurred in the plants treated with atrazine, imazethapyr, or chlorimuron (Figure 1).

MCR biomass following glyphosate application was significantly higher than WCS and ACR; however, MCR dry weight in this treatment accounted for approximately only $10 \%$ of the untreated (Figure 1). The overall magnitude of this difference was small in comparison to the response difference of MCR and ACR with WCS to atrazine 


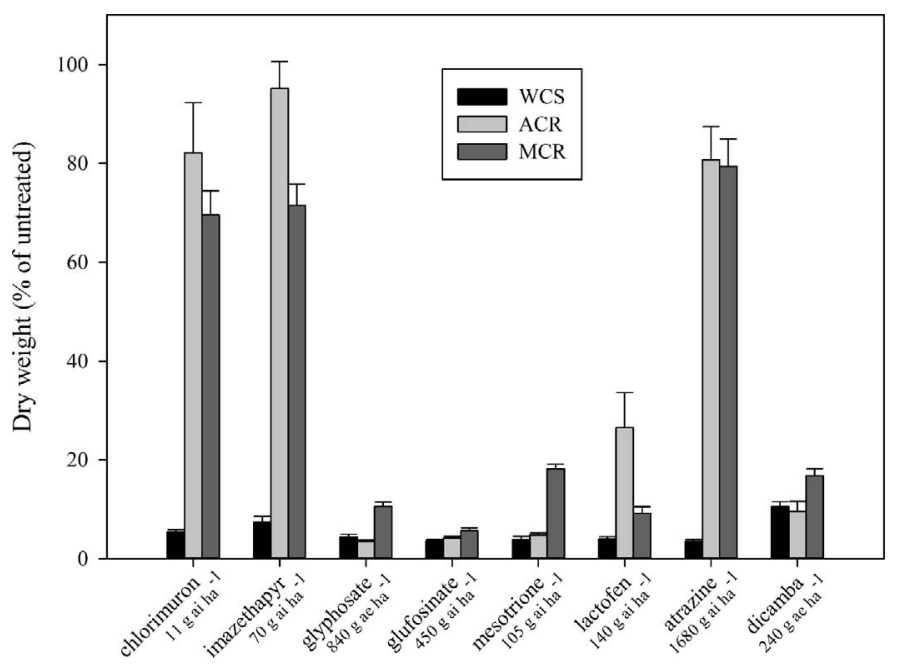

Figure 1. Responses of HPPD-inhibitor resistant (MCR) and sensitive (ACR and WCS) waterhemp populations following foliar applications of herbicides representing seven site-of-action groups under greenhouse conditions. Data are dry weights collected $21 \mathrm{~d}$ after treatment (DAT), and presented as a percent of the untreated ( \pm 1 SEM).

or ALS inhibitors. MCR had the same mean biomass as WCS and ACR following treatment with glufosinate or dicamba (Figure 1). Visual estimates of dicamba injury and injury symptomatology (epinasty and leaf malformation) were generally similar among all three biotypes (Table 5). Estimates for dicamba control of MCR were much greater in the greenhouse than the field, perhaps because more emphasis was placed on evaluating individual plants rather than total biomass reduction in the field.

All MCR plants treated with mesotrione (96 plants in total across two runs of the greenhouse experiment) survived to 21 DAT (when plants were harvested), though the amount of injury varied from plant to plant. Conversely, all replicates (eight plants in total across two runs of the greenhouse experiment) of WCS and ACR were completely controlled with mesotrione by 21 DAT (Table 5). Additionally, the accumulated biomass of MCR following treatment with mesotrione was greater than WCS and ACR. Biomass accumulation of MCR and WCS plants treated with lactofen was significantly less (Figure 1) compared with ACR, a population known to be resistant to $\mathrm{PPO}$-inhibiting herbicides (Patzoldt et al. 2005).

These results demonstrate MCR is less sensitive to HPPD, PSII, and ALS inhibitors and support the conclusions reached by Hausman et al. (2011), Ma et al. (2013), and Guo et al. (2015). Furthermore, results indicate a high percentage of plants survive when labeled use rates of HPPD inhibitors are applied to 10 to $15-\mathrm{cm}$-tall waterhemp. Mesotrione alone or in combination with atrazine applied at the 2 to $5-\mathrm{cm}$ application timing increased control of MCR, although numerous plants survived. In general, PPO inhibitors, glufosinate, and glyphosate provided the greatest control of MCR in both field and greenhouse experiments. HPPD inhibitor resistance is present in multiple states (Heap 2013) and could increase with additional selection intensity (Allen et al. 2011).

\section{Acknowledgments}

The authors thank Syngenta Crop Protection for financial support of this research. We also thank Martin Williams II, Doug Maxwell, and Lisa Gonzini for technical assistance.

\section{Literature Cited}

Allen J, Hinz J, Essner R, Fischer J, Van Wert S (2011) Introducing a new soybean event with glyphosate and HPPD tolerance. Proc North Central Weed Sci Soc 66:144

Bell MS, Hager AG, Tranel PJ (2013) Multiple resistance to herbicides from four site-of-action groups in waterhemp (Amaranthus tuberculatus). Weed Sci 61:460-468

Buhler DD, Hartzler RG (2001) Emergence and persistence of seed of velvetleaf, common waterhemp, woolly cupgrass, and giant foxtail. Weed Sci 49:230-235

Burnside OC, Wilson RG, Weisberg S, Hubbard KG (1996) Seed longevity of 41 weed species buried 17 years in eastern and western Nebraska. Weed Sci 44:74-86

Foes MJ, Liu LX, Tranel PJ, Wax LM, Stoller EW (1998) A biotype of common waterhemp (Amaranthus rudis) resistant to triazine and ALS herbicides. Weed Sci 46:514-520

Guo J, Riggins CW, Hausman NE, Hager AG, Riechers DE, Davis AS, Tranel PJ (2015) Non-target site resistance to ALS inhibitors in waterhemp (Amaranthus tuberculatus). Weed Sci 63:399-407

Hager AG, Wax LM, Bollero GA, Stoller EW (2003) Influence of diphenylether herbicide application rate and timing on common waterhemp (Amaranthus rudis) control in soybean (Glycine max). Weed Technol 17:14-20

Hager AG, Wax LM, Simmons FW, Stoller EW (1997) Waterhemp management in agronomic crops. Univ Ill Bull 855:12

Hager AG, Wax LM, Stoller EW, Bollero GA (2002) Common waterhemp (Amaranthus rudis) interference in soybean. Weed Sci 50:607-610

Hartzler RG, Battles B, Nordby D (2004) Effect of common waterhemp (Amaranthus rudis) emergence date on growth and fecundity in soybean. Weed Sci 52:242-245 
Hartzler RG, Buhler DD, Stoltenberg DE (1999) Emergence characteristics of four annual weed species. Weed Sci 47:578584

Hausman NE, Singh S, Tranel PJ, Riechers DE, Kaundun SS, Polge ND, Thomas DA, Hager AG (2011) Resistance to HPPD-inhibiting herbicides in a population of waterhemp (Amaranthus tuberculatus) from Illinois, United States. Pest Manag Sci 67:258-261

Hausman NE, Tranel PJ, Riechers DE, Maxwell DJ, Gonzini LC, Hager AG (2013) Responses of an HPPD inhibitorresistant waterhemp (Amaranthus tuberculatus) population to soil-residual herbicides. Weed Technol 27:704-711

Heap IM (2013) International Survey of Herbicide Resistant Weeds. http://www.weedscience.org. Accessed April 10, 2013

Hess DF (2000) Light-dependent herbicides: an overview. Weed Sci 48:160-170

Hoss NE, Al-Khatib K, Peterson DE, Loughin TM (2003) Efficacy of glyphosate, glufosinate, and imazethapyr on selected weed species. Weed Sci 51:110-117

Johnson BC, Young BG, Matthews JL (2002) Effect of postemergence application rate and timing of mesotrione on corn (Zea mays) response and weed control. Weed Technol $16: 414-420$

Lally NG, Thompson CR, Peterson D (2010) Palmer amaranth differential response to pyrasulfotole $\&$ bromoxynil. Proc North Central Weed Sci Soc 65:68

Ma R, Kaundun SS, Tranel PJ, Riggins CW, McGinness DL, Hager AG, Hawkes T, McIndoe E, Riechers DE (2013) Distinct detoxification mechanisms confer resistance to mesotrione and atrazine in a population of waterhemp. Plant Physiol 163:363-377

Matsumoto H (2002) Inhibitors of Protoporphyrinogen oxidase: a brief update. Pages 151-161 in Boger P, Wakabayashi K, Hirai K eds. Herbicide Classes in Development. New York, NY: Springer-Verlag

McMullan PM, Green JM (2011) Identification of a tall waterhemp (Amaranthus tuberculatus) biotype resistant to
HPPD-inhibiting herbicides, atrazine, and thifensulfuron in Iowa. Weed Technol 25:514-518

Patzoldt WL, Tranel PJ, Hager AG (2002) Variable herbicide responses among Illinois waterhemp (Amaranthus rudis and $A$. tuberculatus) populations. Crop Prot 21:707-712

Patzoldt WL, Tranel PJ, Hager AG (2005) A waterhemp (Amaranthus tuberculatus) biotype with multiple resistance across three herbicide sites of action. Weed Sci 53:30-36

Sauer J (1955) Revision of the dioecious amaranths. Madrono $13: 5-46$

Sauer J (1957) Recent migration and evolution of the dioecious Amaranths. Evolution 11:11-31

Saxton AM (1998) A macro for converting mean separation output to letter groupings in Proc Mixed. Proc. Ann SAS Users Group Int 23:1243-1246

Steckel LE, Sprague CL (2004) Common waterhemp (Amaranthus rudis) interference in corn. Weed Sci 52:359-364

Steckel LE, Sprague CL, Hager AG, Simmons FW, Bollero GA (2003) Effects of shading on common waterhemp (Amaranthus rudis) growth and development. Weed Sci 51:898-903

Tranel PJ, Riggins CW, Bell MS, Hager AG (2010) Herbicide resistances in Amaranthus tuberculatus: a call for new options. J Agric Food Chem 59:5808-5812

Vyn JD, Swanton CJ, Weaver SE, Sikkema PH (2006) Control of Amaranthus tuberculatus var. rudis (common waterhemp) with pre and postemergence herbicides in Zea mays L. (maize). Crop Prot 25:1051-1056

Woodyard AJ, Bollero GA, Riechers DE (2009) Broadleaf weed management in corn utilizing synergistic postemergence herbicide combinations. Weed Technol 23:513-518

Received July 5, 2015, and approved September 25, 2015.

Associate Editor for this paper: Bradley Hanson, University of California, Davis. 